\title{
Learning Vocabulary via Mobile Phone: Persian EFL Learners in Focus
}

\author{
Saeed Taki \\ Islamic Azad University, Shahreza Branch, Iran \\ Email: taki@iaush.ac.ir \\ Saeed Khazaei \\ Islamic Azad University, Shahreza Branch, Iran \\ Email: saeed.khazaei@gmail.com
}

\begin{abstract}
With encompassing power of cell phones and potentials of mobile learning for language teaching/learning, employing cell phones in language learning seems indispensable. Through exploiting the inherent capabilities of such devices this study investigated the efficacy of multimodal representation of L2 vocabularies for 158 pre-intermediate level $\mathrm{L2}$ learners aged 18-23. Since short-term memory plays an important role in vocabulary learning, they were placed into four different short-term memory (STM) ability groups using visual and verbal STM Tests. Also, cell phone-based vocabulary presentations with different annotations, i.e. pictorial vs. written, were adapted to the cell phone screen to render on learners' cell phones via Bluetooth. Finally, the participants took English vocabulary recognition and recall tests. The statistical analysis of the results showed that presenting learning materials with pictorial or written annotations rather than without annotations to learners with high-visual and high-verbal abilities resulted in better learning. Also, presenting learning materials with pictorial annotation to learners with high-visual ability as well as presenting the materials with written annotation to learners with high-verbal ability resulted in better learning. Low-visual and low-verbal ability groups showed better results under no annotation condition. The findings can provide an appropriate model for designing learning materials for $L 2$ learners.
\end{abstract}

Index Terms - vocabulary learning, multimedia learning, mobile learning, learning and technology

\section{INTRODUCTION}

Among all mobile devices such as mobile phones, Personal Digital Assistants (PDAs), or smart phones mobile phones are probably the most popular and widely used all over the world (Cui \& Wang, 2008). The United Nations (2010) reported that some 4.6 billion people are now mobile phone subscribers, indicating that 67 percent of all the people in the world are affected. Now, mobile phone has not only become an entertainment device (featuring functions such as camera, FM, and MP3 players) but also allows users to access, through the Internet, Personal Digital Assistant (PDA) functions and have video conferences using the state-of-the-art 3G (third generation of mobile phones) network ("Phonehistory," 2009).

Due to these rapid advances in mobile phone technology, it seems that in future mobile phones would replace computers. Consequently, many researchers have started to believe that mobile phones are not only able to support formal and informal learning but also to complete the process of learning via computers.

Since learning English is very popular in non-English speaking countries, developing modern learning tools that support effective English learning is a critical issue in English-language education (Chen \& Chung, 2008). However, advances in the application of mobile technology in language learning and teaching necessarily involve, in the early phases, a challenging process of trial and error, as teachers seek to incorporate new technologies into their students' already complex language-learning lives (Conacher, 2009). According to Bull and Kukulska-Hulme (2009), there is a large body of research on second language learning, but often much of the relevant theory and empirical findings are overlooked by developers of language learning technology support.

Chen, Hsieh, and Kinshuk (2008) quoting Alavi and Leidner (2001) reported that a majority of previous studies have mainly relied on the stimulus-response theory, which probes only the relationship between information technologies (stimulus) and learning outcome (response); future studies should also take the learner's characteristics into consideration in assessing the learning outcome of technology-mediated learning. They also pointed out that the psychological learning process (PLP) of learners is an important mediator that cannot be neglected.

\section{BACKGROUND}

\section{A. Theoretical Framework}

Information is cognitively processed through visual or verbal channels (Jones, 2004; Mayer, 1979, 2005; Paivio, 1986). The basic architecture of information processing model is the multi-store model (Atkinson \& Shiffrin, 1968) 
which consists of three types of memory: Sensory, Short-Term (STM), and Long-Term (LTM). There are studies about the relation between vocabulary acquisition and verbal short-term memory (Greffe, Linden, Majerus, \& Poncelet, 2005; Gupta \& Mac Whinney, 1977).

Working memory is a more contemporary term for short-term memory which conceptualizes memory not as a passive system for temporary storage but as an active system for temporarily storing and manipulating information needed in the execution of complex cognitive tasks like learning, reasoning, and comprehension (Richards \& Schmidt, 2002).Working memory is heavily involved in language learning (Ellis, 1996). In addition, according to Numminen (2002), working memory is an especially significant memory area for learning to read.

Also, in second or foreign language learning, different learners may prefer different solutions to learning problems. For example, some may want explanations for grammatical rules others may not need explanations. Some may feel that writing down words or sentences helps to remember them. Others may find that they remember things better if they are associated with pictures. These are called differences in cognitive style (Richards \& Schmidt, 2002). Generally speaking, in EFL contexts where the target language is not the medium of communication in the society, technology can function as a facilitator in the process of language learning (Rashtchi \& Hajihassni, 2010).

In designing learning materials for mobile phones, the application of multimedia seems useful through which not only could different types of learning materials in the form of annotations be presented to learners with different cognitive styles but also the limitation on the screen size of mobile phones could be solved to some extent.

Research on second language (L2) vocabulary acquisition has revealed that words associated with actual objects or imagery techniques are learned more easily than those without. With multimedia application, it is possible to provide, in addition to the traditional definitions of words, different types of information, such as pictures and videos (Chun \& Plass, 1996). The presence of both pictorial and written cues can facilitate learning, in particular when the corresponding visual and verbal representations are contiguously present in the working memory (Mayer, 2003). According to Jones (2004), researchers have long been interested in examining the effects of pictorial and verbal cues on L2 vocabulary learning, and have found that processing supportive information such as pictures or translations enhances language learning.

It seems suitable to take into consideration theories such as cognitive theory of multimedia and cognitive load theory in applying multimedia in designing learning materials. The case for multimedia is based on the fact that instruction messages should be designed in the light of how human mind works (Mayer, 2005). According to the cognitive theory of multimedia learning which examines how people process separate channels for processing verbal and visual material (dual-channels assumption), each channel can process only a small amount of material at a time (limited capacity assumption), and meaning learning involves engaging in appropriate cognitive processing.

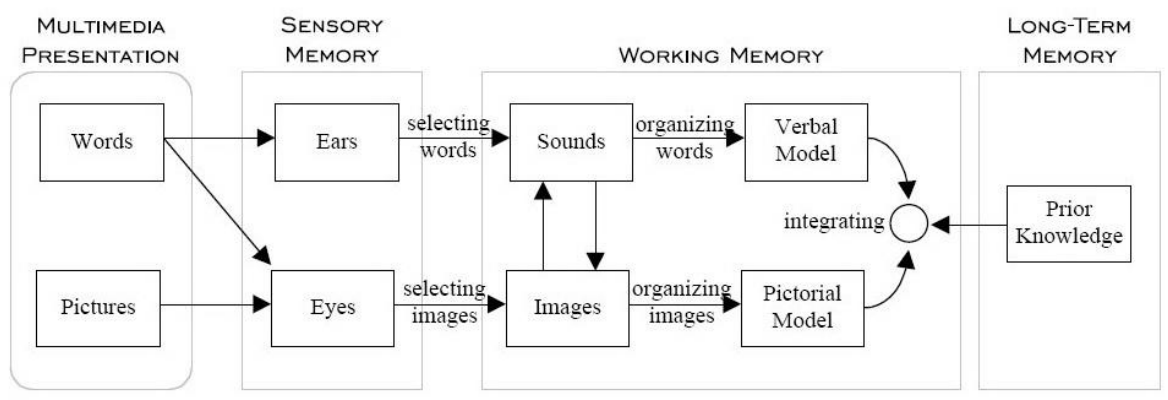

Figure 1. Mayer's cognitive theory of multimedia model (Mayer, 2005, p. 54)

Thus, in this study an attempt was made to design a system in which not only could people learn English anytime and anywhere, but also the learning materials could be presented according to their needs and their PLPs.

\section{B. Research Questions}

This research aimed at investigating the effects of mobile-based presentation of vocabulary definitions, supported with annotations, on the EFL pre-intermediate learners' vocabulary learning. More specifically, the following questions were addressed:

1) Is there any difference in learning between presenting learning materials with annotation (i.e. pictorial vs. written) and those without for learners with high-visual and high-verbal abilities?

2) Is there any difference in learning between presenting learning materials with pictorial annotation and those without for learners with high-visual but low-verbal abilities?

3) Is there any difference in learning between presenting learning materials with annotation and those without annotation for learners with both low-visual and low-verbal abilities?

4) Is there any difference in learning between presenting learning materials with written annotation and those without for learners with low-visual ability but high-verbal ability? 


\section{METHOD}

\section{A. Participants}

The participants in this study were selected from among those enrolled in EFL classes in an Iranian English institute $(\mathrm{N}=158)$. They were selected from 12 classes at the same level of language proficiency (i.e. pre-intermediate level). Their age range was between 19 and 23 years. Each learner had a different STM ability for processing different LCR (Learning Content Representation) types; that is, LCR with or without pictorial or written annotations. Thus, STM was considered as a criterion to divide learners into four groups:

Group 1 (G1): learners with higher visual and verbal abilities

Group 2 (G2): learners with higher visual but lower verbal abilities

Group 3 (G3): learners with both lower visual and lower verbal abilities

Group 4 (G4): learners with lower visual but higher verbal abilities

The characteristics of the four groups are represented in Figure 2.

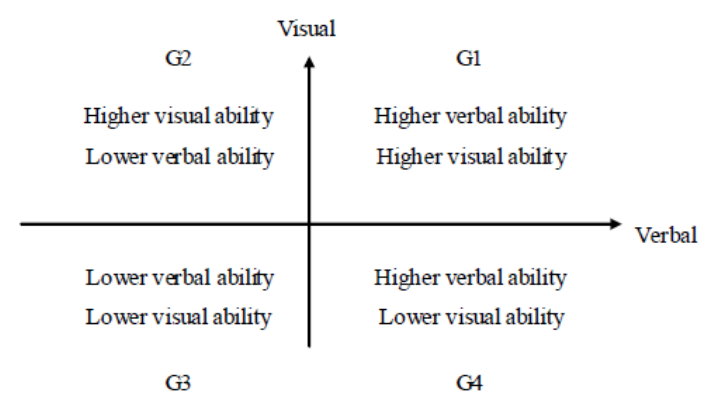

Figure 2. Grouping learners in terms of their visual and verbal abilities

\section{B. Materials}

The materials used in this study are a) a language proficiency test, b) a vocabulary level test, c) a background questionnaire, d) software package, e) visual and verbal STM tests, and f) recognition and recall tests.

Proficiency test: to make sure that the participants were at the same language proficiency level, they were given the Nelson English Language test.

Vocabulary level test: since there should be a clear and sensible goal for vocabulary learning (Nation \& Waring, 1997), a vocabulary level test of 50 items was prepared, using frequency method. In fact, frequency items information provides a rational basis for making sure that learners get the best return for their vocabulary learning effort (Nation \& Waring, 1997). The test was administered to assess the learners' original knowledge of words and to prevent the inclusion of words which learners became familiar with in the learning phase of the experiment. The word items for the vocabulary test were selected from Bauman's General Service List (GSL), which consists of 2284 words. One word from every 40 words was selected, starting from the 40th word (40 2203 'more') to the 2000th word (15 2000 'scenery').The Bauman's GSL is based on the Brown's corpus which contains 1000,000 words. Beside every word there are two numbers: the first one indicates the order of the word item in the list which is based on the frequency of the word in Brown's corpus and the other number indicates the frequency of occurrence of the word in Brown's corpus. Since New Interchange series was taught in that language institute, the vocabulary lists at the end of those books were checked to avoid using words which the learners had already learned. When learners completed the vocabulary level test, it became clear that nearly all the learners were familiar with words up to the word 'absolute' (1280 62 'absolute'). Therefore, 18 words for the third phase of learning were selected from 1500th 'wisdom' (1500 44 'wisdom') onward. For each word item, the following three types of representation were prepared:

Type 1 represents the English word, pronunciation, part of speech, and the Persian meaning of the word.

Type 2 represents the materials shown in type 1 plus the written annotation (i.e. the example sentence of the item).

Type 3 represents the materials shown in type 1 plus the pictorial annotation.

Examples of three different representation types, for the word 'dig' are shown in Figure 3.

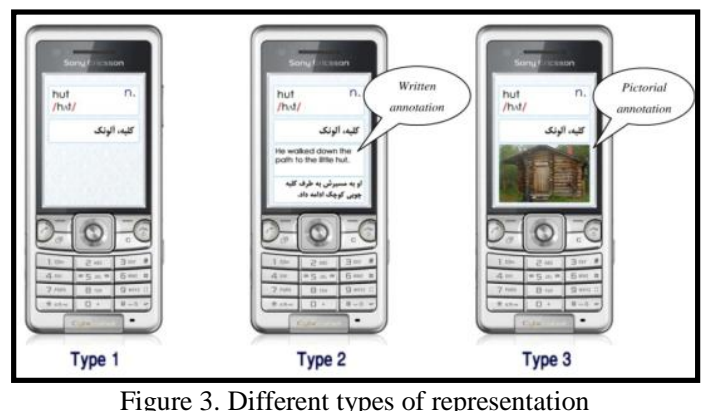


Background questionnaire: an open-ended questionnaire was prepared to make it possible for learners to express their thoughts and ideas without limitation as related to using mobile phones and whether they were interested in participating in the study.

Software: it was designed to conduct the main phases of the study. The installation, its different parts, and how to use it were all described.

Visual and verbal STM tests: 40 questions were prepared to test the learners' visual and verbal ability; that is, 20 questions were prepared for testing the visual ability and 20 questions for testing the verbal ability. The STM tests were prepared based on the model proposed by Chen and Chen (2005). As they have reported, personalized service is important on the Internet, especially in web-based learning. Generally, most personalized systems consider learners' preferences, interests, and browsing behaviors in providing personalized services. However, learners' ability is usually neglected as an important factor in implementing personalization mechanisms. So, they proposed a personalized elearning system based on Item Response Theory (PEL-IRT), which considers both course material difficulty and learner ability to provide individual learning paths for learners.

Figure 4. illustrates the proposed system architecture, which can be divided into two main parts according to system operation procedures, that is, front-end and back-end parts. The front-end part manages communication with learners and records the learner's behavior. Meanwhile, the back-end part aims to analyze learner ability and select appropriate course materials for learners based on the estimated learner ability.

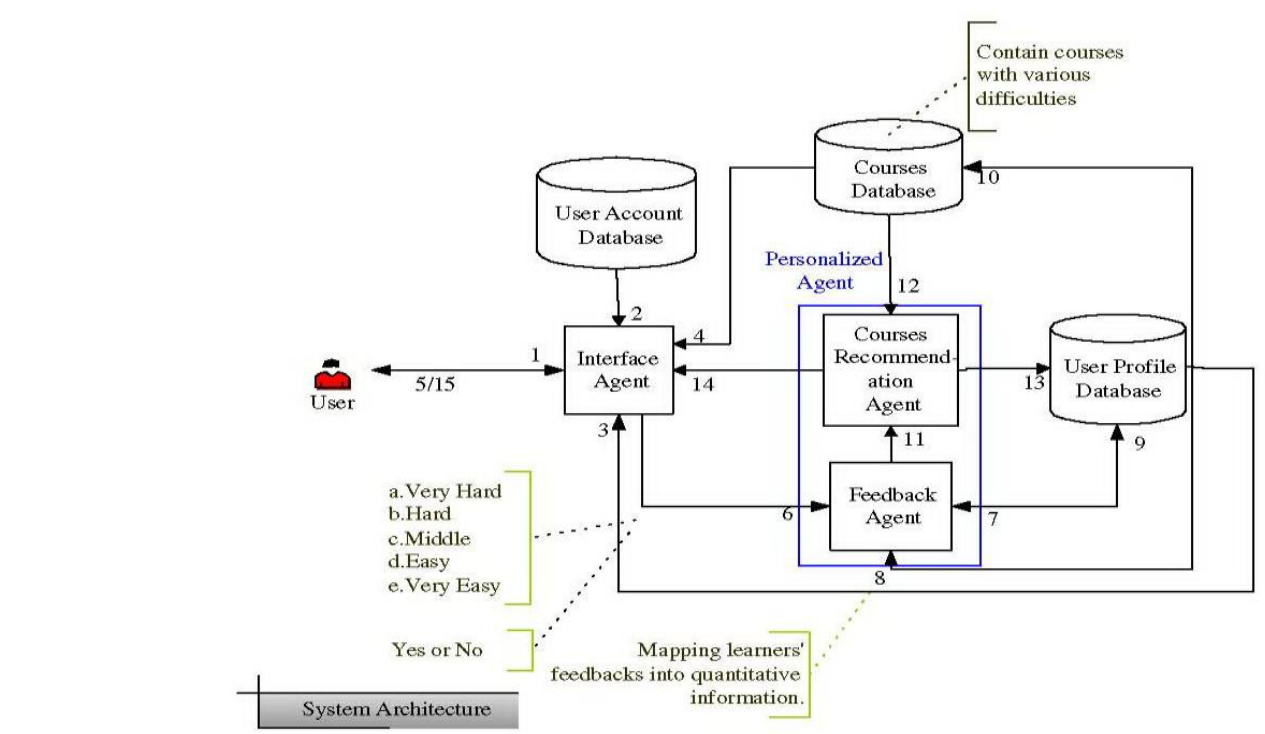

Figure 4. System architecture (Numbers $1 ; 2 ; \ldots ; 15$ indicate the procedure of system operation) (Chen \& Chen, 2005, p. 3)

English vocabulary recognition and recall (EVRR) tests: these tests are often used to examine learners' vocabulary knowledge (Jones, 2004). 18 recognition questions and 18 recall questions were prepared for testing the learners' vocabulary learning. Although the framework for making recognition and recall tests was like the one extracted from the study done by Chen, Hsieh, and Kinshuk (2008), their reliability was calculated through Cronbach's alpha and it was found to be 0.81 .

\section{Procedure}

The study took place in the language laboratory of the institute in four phases:

Phase I: Introduction. In this phase, all the details and objectives of the experiment were explained. Then, the background questionnaire was distributed among the learners to complete.

Phase II: STM ability test. Each learner was provided with a computer for STM test. First, they took part in a visual STM ability test and then a verbal STM test. Each question in these two tests (i.e. verbal and visual) comprised two subparts. Regarding the visual section of the test initially a picture was displayed for 08.00 seconds; then, a question was asked about the picture. The learners were given 06.00 seconds to answer the question. Concerning the verbal test, first a sentence was displayed for 08.00 seconds, then a question addressing the sentence was asked; the learners had to answer in 06.00 seconds. Afterwards, each learner's answers were recorded and the learners were assigned two types of score (i.e. raw score and standard score with a mean of 0.000 and a standard deviation of 01.00). On the basis of their $\mathrm{z}$ scores of visual and verbal STM abilities, the participants were divided into four groups: 55 in group1 (G1), 28 in group 2 (G2), 48 in group 3 (G3), and 27 in group 4 (G4).

Phase III: Learning new vocabulary items. In this phase each participant was assigned a mobile phone to learn 18 new English vocabulary items. All items were sent to their mobile phones via Bluetooth. Each item was presented to the 
learners for about 120 seconds. Since the learners were not able to exit the program from the time they opened the target files until they ended the program, the researcher had full control over all the mobile phones.

In order to counterbalance the effect of the order of presentation, a $3 \times 3$ Latin Square (LS) design was employed. According to Montgomery (1991), one of the frequent uses of LS is to counterbalance the various sequences in which an independent variable might take place. In LS, each of the 3 digits (i.e. 1, 2, 3) would appear just once in each row and column. Figure 5 shows a $3 \times 3$ Latin Square.

\begin{tabular}{|l|l|l|}
\hline 1 & 2 & 3 \\
\hline 2 & 3 & 1 \\
\hline 3 & 1 & 2 \\
\hline
\end{tabular}

Figure 5.The $3 \times 3$ Latin square

In this research the first six words were presented to the first participant in type1, then 6 words in type 2, and finally 6 words in type 3 . At the same time, the second participant received the first 6 words in type 2, then 6 words in type 3 , and the last six words in type 1 .

Phase IV: Testing phase. After the third phase (i.e. learning phase) the learners took EVRR tests. First, they took recognition tests which consisted of 18 multiple-choice questions and then they took the recall tests which consisted of 18 questions, too. The frameworks for making recognition and recall questions were the ones adopted from the study done by Chen et al. (2008).

\section{RESULTS AND DISCUSSION}

Concerning question 1 , the recognition scores for type 2 and type 3 learning materials obtained by learners placed in G1 were not higher than those for type 1 learning materials. As Table 1 displays, the recall scores for type 2 and type 3 learning materials were higher than those for type 1 learning materials for learners in $\mathrm{G} 1(\mathrm{p}=0.000)$. Also, the average score for type 2 and type 3 learning materials was higher than that for type 1 learning materials $(\mathrm{p}=0.002)$.

TABLE 1.

DESCRIPTIVE STATISTICS: RECOGNITION SCORES, RECALL SCORES, AND AVERAGE SCORES OF GROUP 1

\begin{tabular}{|c|c|c|c|c|c|c|c|c|c|}
\hline \multirow{2}{*}{ Group } & \multirow{2}{*}{$\begin{array}{l}\text { Number of } \\
\text { subjects }\end{array}$} & \multirow{2}{*}{ Age } & \multirow{2}{*}{ Type } & \multicolumn{2}{|c|}{ Recognition Score } & \multicolumn{2}{|c|}{ Recall Score } & \multicolumn{2}{|c|}{ Average Score } \\
\hline & & & & Mean & Std. Error & Mean & Std. Error & Mean & Std. Error \\
\hline \multirow{3}{*}{ Group 1} & \multirow{3}{*}{55} & \multirow{3}{*}{21.5} & 1 & 2.2 & 0.145 & 1.02 & 0.120 & 1.6091 & 0.10355 \\
\hline & & & 2 & 3.31 & 0.147 & 2.02 & 0.120 & 2.6636 & 0.09971 \\
\hline & & & 3 & 3.73 & 0.123 & 2.4 & 0.177 & 3.0636 & 0.12313 \\
\hline
\end{tabular}

As for question 2, the recognition scores for type 3 learning materials obtained from the participants in G2, shown in Table 2, were higher than those for type 1 ( $\mathrm{p}=0.000)$. Recall scores for type 3 learning materials were higher than those for type 1 learning materials for the learners in $\mathrm{G} 2(\mathrm{p}=0.000)$. Also, the average score for type 3 learning material was higher than that for type 1 learning materials for learners in $\mathrm{G} 2(\mathrm{p}=0.000)$.

TABLE 2.

DESCRIPTIVE STATISTICS: RECOGNITION SCORES, RECALL SCORES, AND AVERAGE SCORES OF GROUP 2

\begin{tabular}{|c|c|c|c|c|c|c|c|c|c|}
\hline \multirow{2}{*}{ Group } & \multirow{2}{*}{$\begin{array}{l}\text { Number of } \\
\text { subjects }\end{array}$} & \multirow{2}{*}{ Age } & \multirow{2}{*}{ Type } & \multicolumn{2}{|c|}{ Recognition Score } & \multicolumn{2}{|c|}{ Recall Score } & \multicolumn{2}{|c|}{ Average Score } \\
\hline & & & & Mean & Std. Error & Mean & Std. Error & Mean & Std. Error \\
\hline \multirow{3}{*}{ Group 2} & \multirow{3}{*}{28} & \multirow{3}{*}{21.53} & 1 & 1.82 & 0.193 & 1 & 0.154 & 1.4107 & 0.14785 \\
\hline & & & 2 & 1.68 & 0.163 & 0.79 & 0.166 & 1.2321 & 0.14430 \\
\hline & & & 3 & 3.82 & 0.200 & 3.04 & 0.174 & 3.4286 & 0.16808 \\
\hline
\end{tabular}

As far as question 3 is concerned, the recognition scores for type 1 learning materials, as shown in Table 3, were significantly better than those for type 2 or type 3 learning materials for learners in $\mathrm{G} 3(\mathrm{p}=0.000)$. Recall scores for type 1 learning materials were not better than those for types 2 or 3 learning materials for the learners placed in G3. Also, the average score for type 1 learning material was better than those for type 2 or type 3 learning materials for the learners placed in $\mathrm{G} 3(\mathrm{p}=0.000)$.

TABLE 3.

DESCRIPTIVE STATISTICS: RECOGNITION SCORES, RECALL SCORES, AND AVERAGE SCORES OF GROUP 3

\begin{tabular}{|c|c|c|c|c|c|c|c|c|c|}
\hline \multirow{2}{*}{ Group } & \multirow{2}{*}{$\begin{array}{l}\text { Number of } \\
\text { subjects }\end{array}$} & \multirow{2}{*}{ Age } & \multirow{2}{*}{ Type } & \multicolumn{2}{|c|}{ Recognition Score } & \multicolumn{2}{|c|}{ Recall Score } & \multicolumn{2}{|c|}{ Average Score } \\
\hline & & & & Mean & Std. Error & Mean & Std. Error & Mean & Std. Error \\
\hline \multirow{3}{*}{ Group 3} & \multirow{3}{*}{48} & \multirow{3}{*}{21.22} & 1 & 3.83 & 0.134 & 2.79 & 0.157 & 3.3125 & 0.12599 \\
\hline & & & 2 & 1.92 & 0.118 & 0.98 & 0.117 & 1.4479 & 0.10123 \\
\hline & & & 3 & 1.9 & 0.153 & 0.79 & 0.126 & 1.3438 & 0.11924 \\
\hline
\end{tabular}


As for question 4, as Table 4 represents, the recognition scores for type 2 learning materials obtained by the learners placed in G4 were higher than those for type $1(\mathrm{p}=0.000)$. Recall scores for type 2 learning materials were higher than those for type 1 learning materials for the learners in $\mathrm{G} 4(\mathrm{p}=0.000)$. Also, the average score for type 2 learning materials was higher than that for type 1 learning materials $(0.000)$.

TABLE 4.

DESCRIPTIVE STATISTICS: RECOGNITION SCORES, RECALL SCORES, AND AVERAGE SCORES OF GROUP 4

\begin{tabular}{|c|c|c|c|c|c|c|c|c|c|}
\hline \multirow{2}{*}{ Group } & \multirow{2}{*}{$\begin{array}{l}\begin{array}{l}\text { Number of } \\
\text { subjects }\end{array} \\
\end{array}$} & \multirow{2}{*}{ Age } & \multirow{2}{*}{ Type } & \multicolumn{2}{|c|}{ Recognition Score } & \multicolumn{2}{|c|}{ Recall Score } & \multicolumn{2}{|c|}{ Average Score } \\
\hline & & & & Mean & Std. Error & Mean & Std. Error & Mean & Std. Error \\
\hline \multirow{3}{*}{ Group 4} & \multirow{3}{*}{27} & \multirow{3}{*}{21.18} & 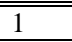 & 2.22 & 0.147 & 1 & 0.169 & 1.6111 & 0.12892 \\
\hline & & & 2 & 4.33 & 0.141 & 3.44 & 0.222 & 3.8889 & 0.17158 \\
\hline & & & 3 & 2.41 & 0.134 & 1.15 & 0.183 & 1.7778 & 0.12327 \\
\hline
\end{tabular}

Since the recall test is a test of productive knowledge and the recognition test is a test of receptive knowledge, receptive recognition is somewhat easier than productive recall (Richards \& Schmidt, 2002). The case for the results of this study is in line with this observation. In other words, the learners' recognition scores were higher than the recall ones. These results could, to some extent, be attributed to the role of learners' visual and verbal abilities.

The results of Tables 1, 2, and 4 are in line with the dual coding theory (DCT) in that the addition of written or pictorial annotations could help in facilitating learning. Also, the answer to the third question supports the idea that presenting the learning materials with annotation could inhibit more rather than it may facilitate the learning process (i.e. cognitive load theory).

According to the dual-coding theory, learning is more effective when learners use more than one sensory modality, for instance, verbal and visual processing together and when connections are clearly made between information in each modality (Mayer, 2003). The results of the study are in line with DCT theory, however, this was not the case for the learners with both low-visual and low-verbal abilities. In other words, although according to Tabbers, Martens, and Merrienboer (2004) strategies such as physically integrating text and picture and replacing written or on-screen text with spoken texts reduce the extraneous load of multimedia instructions and thus increase the effectiveness of the learning process, the results of this study are not in line with such theories since L2 learners with low visual and low verbal abilities in this study did not perform well on the recognition and recall tests of the materials when presented with pictorial and written annotations.

Also, the results of the study support the results reported by Chen et al. (2008), in which it was demonstrated that the learners with high-verbal and high-visual ability learned the materials with pictorial or written annotations better. On the other hand, the learners with both low-visual and low-verbal abilities do not benefit much from learning materials with pictorial or written annotation. According to this study, although the learners with good visual ability but low verbal ability perform well on recognition tests, they do not perform well on recall tests. Likewise, the same result is true for the learners with high verbal but low visual ability and learning materials with written annotation.

\section{CONCLUSION}

Based on the results of the study the following points can be made:

- Learners with both high-visual and high-verbal ability, learn the learning materials with written or pictorial annotation better than the learning materials without annotation. Although this is true for the recall test, it is not the case for the recognition test.

- Presenting the learning materials with pictorial annotation to learners with high-visual but low-verbal ability results in better vocabulary learning.

- Presenting the learning materials without annotation to learners with both low-visual and low-verbal abilities results in better vocabulary learning than presenting the types with pictorial or written annotation. Although this is true for recognition tests in recall tests, they cannot be justified for the recall tests.

- Learners with low-visual ability but high-verbal ability learn the learning materials with written annotation better than those without annotation.

Regarding the potential of mobile phones in the realm of teaching and language learning, it seems necessary to go beyond and apply them in teaching and learning other skills and sub-skills.

\section{REFERENCES}

[1] Atkinson, R. C., \& Shiffrin, R. M. (1968). Human memory: A proposed system and its control processes. In K.W. Spence \& J.T. Spence (Eds.), The Psychology of Learning and Motivation, 2, 89-195.

[2] Bauman, B. (1995). About the GSL. Retrieved March 20, 2009 from http://www.jbauman.com/aboutgsl.html

[3] Brown, J. D. (1988). Understanding research in second language learning. NY: Cambridge University Press.

[4] Bull, S., \& Kukulska-Hulme, A. (2009). Theory- based support for mobile language learning: Noticing and recording. IJIM, $3(2), 12-18$ 
[5] Chen, C. M., Lee, H. M., \& Chen, Y. (2005). Personalized e-learning system using item response theory. Computers and Education, 44(3), 237-255.

[6] Chen, Ch.-M., \& Chung, Ch.-J. (2008). Personalized mobile English vocabulary learning system based on item-response theory and learning memory cycle. Journal of Computer and Education, 51 (2), 624-645.

[7] Chen, Ch.-M., \& Hsu, Sh.-H. (2008). Personalized mobile learning system for supportive effective English learning. Educational Technology and Society, 11 (3), 153-180.

[8] Chen, N.-S., Hsieh, Sh.-W., \& Kinshuk. (2008). The effects of short-term memory and content representation type on mobile language learning. Journal of Learning and Technology, 12, 93-113.

[9] Chun, D., M., \& Plass, J. L. (1996). Effects of multimedia annotations on vocabulary acquisition. The Modern Language Journal, 80, 183-198.

[10] Coe, N., \& Fowler, W. S. (1976). Nelson English Language Tests. London: Butler and Tanner Ltd.

[11] Conacher, J. (2009, November). Using technologies in learning, teaching and research: Challenges and opportunities for the language Profession. Paper presented at the conference of Technology Enhanced Language Teaching and Learning, London, Vernon.

[12] Cui, G., \& Wang, Sh. (2008). Adopting cell phones in EFL teaching and learning. Journal of Educational Technology Development and Exchange, 1, 69-80.

[13] Ellis, N.C. (1996). Working memory in the acquisition of vocabulary and syntax: Putting language in good order. The Quarterly Journal of Experimental Psychology, 49(1), 234-250.

[14] Greffe, Ch., Linden, M. V., Majerus, S., \& Poncelet, M. (2005). Relations between vocabulary development and verbal short term memory: The relative importance of short-term memory for serial order and item information. Journal of Experimental Child Psychology 93 (2), 95-119.

[15] Gupta, P., \& Whinney, B. M. (1997). Vocabulary acquisition and verbal short-term memory: computational and neural bases. Brain and Language, 59, 267-333.

[16] Hopper, H.U., Joiner, R., Milrad, M., \& Shrples, M. (2003). Guest editorial: Wireless and mobile technology in education. Journal of Computer Assisted Learning, (19), 255-259.

[17] Hully, J., Proctor, S., \& Richards, J.C., (2005). New Interchange ( $3^{\text {rd }}$ ed.). UK: Cambridge University Press.

[18] Jones, L., (2004). Testing L2 vocabulary recognition and recall. Learning and Technology, 8(3), 122-143.

[19] Longman dictionary of contemporary English ( $4^{\text {th }}$ ed.). London: Pearson Education Limited.

[20] Kennedy, C. \& Levy, M. (2008). Using SMS to support beginners' language learning. Recall, 20 (3), 315-330.

[21] Klas, W. \& Zaharieva, M. (2004). Mobilearn: An open approach for structuring content for mobile learning environments (pp. 114-124). Berlin: Springer.

[22] Mayer, R. E., 1979. Can advance organizers influence meaningful learning? Review of Educational Research, 49(2), $371-383$.

[23] Mayer R. E. (2003). Elements of a science of e-learning. Educational Computing Research, 29 (3), 297-313.

[24] Mayer, R. E. (Ed.) (2005). The Cambridge Handbook of multimedia learning. Cambridge: Cambridge University Press.

[25] Montgomery, D. C. (1991). Design and analysis of the experiments. NY: John Wiley \& Sons.

[26] Nation, P. \& Waring, R. (1997). Vocabulary size, text coverage and word lists. Retrieved March 27, 2010, from http://www.fltr.ucl.ac.be/fltr/GERM/ETAN/bibs/vocab/cup.html

[27] Paivio, A. (1986). Mental representations: A dual coding approach. Oxford: Oxford University Press.

[28] Pieri,M. \& Diamantini, D. (2008). from E-learning to mobile learning: New opportunities. International Journal of Knowledge and Learning, 4 (2-3), 176-188.

[29] Rashtchi, M. \& Hajihassani, H. (2010). Blog-assisted language learning: A possibility in teaching reading to Iranian EFL learners. International Journal of Language Studies, 4(4), 245-362.

[30] Richards, J. C., \& Schmidt, R. (2002). Dictionary of language and applied linguistics (3 ${ }^{\text {rd }}$ ed.). England: A Pearson Education Book.

[31] Reis, J. C. \& Bonacian, R. \& Martins, M. C. (2009). Using multimedia in the mobile collaborative learning. Research, Reflection, and Innovation in Integrating ICT in Education, 869-873.

[32] Sharples, M. (2000). The design of personal mobile technologies for lifelong learning. Computer and Education, 34 (4), $177-$ 193.

[33] Sweller, J. (1988). Cognitive load during problem solving: Effects on learning. Cognitive Science, 12, 257-285.

[34] Tabbers, H.K., Martens, R.L. \& Merrienboer, J.J. (2004). Multimedia instructions and cognitive load theory: Effects of modality and cueing. British Journal of Educational Psychology, 74, 71-81.

[35] United Nations [UN], (2010). 67 Percent of people have cell phones. Retrieved March 25, 2010 from http://www.stltoday.com/stltoday/news/stories.nfs/world/story.

Saeed Taki is currently an EFL teacher in the English Department, at Islamic Azad University, Shahreza Branch, IRAN. He holds a $\mathrm{PhD}$ in TEFL and his main areas of interest include cultural studies and (critical) discourse analysis, and foreign language teaching methodology.

Saeed Khazaei is an M.A. graduate in the field of teaching English as a foreign language. He did his M.A. in TEFL at Islamic Azad University, Shahreza Branch, IRAN. He is seriously involved in developing learning materials using modern technology. 